\title{
Research on Species Ecological Adaptability of Shrub Vegetation of Highway Slope
}

\author{
JI Gui-bin ${ }^{1,2, ~ a, ~ L I A N G ~ L i ~ 1, b ~}$, ZHAO Ying ${ }^{3, c}$, LI Xi-lin ${ }^{2, d}$ \\ ${ }^{1}$ School of Resources \& Civil Engineering, Northeastern University, Shenyang 110819, China \\ ${ }^{2}$ College of Architecture and Engineering, Liaoning Technical University, Fuxin 123000, China \\ ${ }^{3}$ Institute of Rock and Soil Mechanics, Chinese Academy of Sciences, Wuhan 430071,China \\ antu@163.com, ${ }^{\mathrm{b}}$ LL-NEU@163.COM, ${ }^{\mathrm{c}}$ yzhao@whrsm.ac.cn, ${ }^{\mathrm{d}}$ leexilin501@163.com
}

Keywords: Highway slope; vegetation protection; ecological adaptation; Analytic Hierarchy Process; shrub plants

Abstract. In order to optimize and select the plants which are suitable for highway slope, this paper chose the vegetation on Guanghe Highway as the research object to carry out the study on how to select plants for highway slope. Based on the experiment of cultivating eight different kinds of subshrub plants which grows well in local environment, this research was to evaluate the adaptability of the plants species by using Analytic Hierarchy Process. The results revealed that Crotalaria pallida Ait, Cajanus cajan (Linn) Millsp, and Tephrosia candida performed the best among the eight kinds of shrub plants, with a better ecological suitability and function of slope protection. Indigofera amblyatha and L. Davidii Franch were the second. Rhodomyrtus tomentosa Ait and Hypericum monogynum Linn were the worst. Therefore, we suggest that Crotalaria pallida Ait, Cajanus cajan (Linn) Millsp and Tephrosia candida should be the preferred choice for slope protection plant for Guanghe Highway. The result of this research can serve as a theoretical foundation and technical support for the highway vegetation construction of Guangzhou and subtropical area.

\section{Introduction}

The total mileage of Chinese Highway had reached 104,500 km by the end of 2013, ranking the first in the world ${ }^{[1]}$. The mass construction of highway network gave rise to large amount of bare slope, causing a series of problems like water and soil loss, destruction of ecological environment, geological disasters, and even negative effects on people's lives and property ${ }^{[2]}$. For this reason, the realization of sustainable development of highway slope environmental protection has great historical and realistic significance.

The study of highway slope eco-protection system has aroused the attention of road department and many researchers steadily in the process of highway construction ${ }^{[3-4]}$. It is clearly prescribed in Specifications for Design of Highway Subgrades that grass planting, turfing and tree planting should be used in preference as the vegetation protection on the highway slope ground which is vegetative. The chosen grass seeds should be determined by the purpose of protection, climate, soil property and construction season, etc ${ }^{[5]}$. So far, achievements in terms of recovery technology for slope vegetation have been made in areas with good growing environment which have normal temperature and rainfall ${ }^{[6-8]}$. However, there has been relatively little scientific study on restoration research of highway vegetation in subtropical areas which have the issues of sever water and soil loss, large amount of rainfall, unequal distribution of rainfall. There are even less shrub vegetation research suitable for southern climate, soil, etc.

Based on that, this paper studied highway slope vegetation construction from Guangzhou to HeYuan, and launched selective research of highway slope subshrub vegetation. Preliminarily we selected the obtaining excellent shrub species of slope counterfort virescence and water \& soil conservation by making use of local research and analysis. Then we carried on the unicast experiment study, to assess the eco-adaptability of these species as a whole, and selected the shrub plants for the vegetation construction protection lawn suitable for this place, which can provide a reliable reference for highway slope vegetation construction of Guangzhou and even subtropical areas. 


\section{Materials and Methods}

Experimental Material. Considering the climate, soil and vegetation growth state in Guangzhou, we select eight different kinds of subshrub plants as the material of unicast test based on Primary Principle. They are Indigofera amblyatha, L. Davidii Franch, Hypericum monogynum Linn, Cajanus cajan (Linn.) Millsp, Tephrosia candida, Rhodomyrtus tomentosa Ait, Crotalaria pallida Ait and Amorpha fruticosa Linn. .

An Overview of Test Site.This test is conducted on Guanghe Highway K2+900 K23+200 section from Guangzhou to Heyuan, 370 meters above the sea level. This area is subjected to the influence of subtropical oceanic monsoons and has a mild and moist climate, with sufficient sunlight, small temperature difference, long summer and short frost season. The effect of heat and water is a benefit to the growth of plants, on the other hand, the threat of natural disaster is great. The average annual temperature of this area is 21.8 degree Celsius, with an extreme low temperature of -0.3 degree Celsius, and extreme high temperature of 39.1 degree Celsius. The average annual precipitation is $1680.5 \mathrm{~mm}$, focused from April to September. There is limited land resource around the highway, but the types of land are varied, which belong to south subtropical latosolic red soil distribution area, including latosolic red soil, mountain red soil, mountain yellow soil and mountain meadow soil. The natural soil moisture content rate is from $12.10 \%$ to $24.30 \%$, while the specific gravity of soil particle is $2.64-2.74 \cdot \mathrm{cm}^{-3}$. The organic content rate is from $1.63 \%$ to $4.011 \%$, and the soil is mainly acid with a $\mathrm{pH}$ from 4.15 to 6.79 .

Design of Experiment. The size of the shrub experiment field is $1 \mathrm{~m} \times 2.5 \mathrm{~m}$ and it is designed to sow 200 seeds per square meter with a germination rate of 70\%. After sowing the seeds, the land should be fertilized by compound fertilizer, calcium superphosphate, organic fertilizer (foul manure).

Fluency Indices and Methods. Fluency indices include quantitative record index (above-ground biomass, under-ground biomass, growth height, root depth, coverage, density, and green period etc) and qualitative record index (greenness, growth rate, homogeneity, visual effect, thermostability, cold endurance, drought tolerance, disease and pest resistance, and barren resistance ), among which quantitative index is the result of that got from the experiment on August 15,2010, namely the index after a growth cycle, and qualitative index is the average of results of four annual observations. The way of determination of the index is: above-ground biomass is the dry weight of above ground plants $\left(\mathrm{kg} \cdot \mathrm{m}^{-2}\right)$; under-ground biomass is the dry weight of $\operatorname{root}\left(\mathrm{kg} \cdot \mathrm{m}^{-2}\right)$; growth height is the absolute growth height of plant $(\mathrm{cm})$; root depth is the length of the main root $(\mathrm{cm})$; coverage is the quotient of planimetric area and area of plot for the whole community of plant(\%); density is the number of plant in quadrat(plant $\cdot \mathrm{m}^{-2}$ ); green period is the day number of plant from seeding stage to withering stage(d). Qualitative record index uses NTEP (American national law rating program The National Turfgrass Evaluation Program) to record. The measurement of greenness uses ocular estimate ${ }^{[9]}$. The testers grade the lawn according to their subjective impression and personal preference. The standard for evaluation is: olivine: 1 3 points; aqua or celadon: 3 5 points; medium green: $5 \sim 7$ points; dark green: 7 9 points. The measurement of growth rate adopts intra-class comparison. The standard for evaluation is: a lower speed of growth rate compared with other plants: 1 3 points; a normal speed of growth rate compared with other plants: 3 5 points; a relatively faster speed of growth rate compared with other plants: 5 7 points; a faster speed of growth rate compared with other plants: 7 9 points. Homogeneity, visual effect, thermostability, cold endurance, drought tolerance, disease and pest resistance, and barren resistance all adopt ocular estimate. The standard for evaluation is: a relatively bad performance: 1 3 points; an average performance: 3 5 points; a relatively good performance: 5 7 points; a very good performance: 7 9 points.

The Eco-adaptability Assessment of Subshrub Plants. We utilize Analytic Hierarchy Processing to assess the eco-adaptability of subshrub plants. Analytic Hierarchy Processing was brought forward by A.L. Saaty, an American operational researcher in 1970s ${ }^{[10-11]}$. This method can quantify qualitative factors making the assessment more scientific. The method of AHP can analyze all factors into related and orderly levels and make them methodized. It gives quantitative expresses between every two factors from objective facts, and identifies the weights of all factors. Using AHP to do 
decision-making analysis, one should firstly set up weights of all factors, apply proportion criteria to compare every two factors, and construct judgment matrix. The next step is to calculate weights of all factors, and check consistency according to the results ${ }^{[12]}$. The consistency check is as follows:

The first step: Calculate consistency index C.I.

C.I. $=\frac{\lambda_{\max }-m}{m-1}$

In the formula, $\lambda_{\max }$ is the largest eigenvalue of the judgment matrix, $\mathrm{m}$ is the order of the judgment matrix;

The second step: Calculate consistency ratio C.R.

$$
\text { C.R. }=\frac{\text { C.I. }}{\text { R.I. }}
$$

In the formula, R.I. is average random consistency index (from Table 1). When C.R. $<0.10$, it is normally considered that the consistency of the judgment is acceptable.

Table 1. The R..I. Table of multistage judgment matrix

\begin{tabular}{rlllllllll}
\hline Degree & 1 & 2 & 3 & 4 & 5 & 6 & 7 & 8 & 9 \\
\hline R.... & 0.00 & 0.00 & 0.58 & 0.90 & 1.12 & 1.24 & 1.32 & 1.41 & 1.45 \\
\hline
\end{tabular}

\section{Result and Analysis}

The Eco-adaptability Analysis of Subshrub Plants. The observation result of subshrub plant eco-adaptability test is as shown in Table 2.

Table 2. The observation result of subshrub plant eco-adaptability test

\begin{tabular}{|c|c|c|c|c|c|c|c|c|}
\hline & G1 & $\mathrm{G} 2$ & G3 & G4 & G5 & G6 & G7 & G8 \\
\hline Plant Name & $\begin{array}{l}\text { Indigofera } \\
\text { amblyatha }\end{array}$ & $\begin{array}{l}\text { Davidii } \\
\text { Franch }\end{array}$ & \begin{tabular}{|l|} 
Hypericum \\
monogynum \\
Linn
\end{tabular} & $\begin{array}{c}\text { Cajanus cajan } \\
\text { (Linn.) Millsp }\end{array}$ & $\begin{array}{l}\text { Tephrosia } \\
\text { candida }\end{array}$ & \begin{tabular}{|l|} 
Rhodomyrtus \\
tomentosa \\
Ait.
\end{tabular} & $\begin{array}{l}\text { Crotalaria } \\
\text { pallida Ait }\end{array}$ & $\begin{array}{l}\text { Amorpha } \\
\text { fruticosa } \\
\text { Linn } \\
\end{array}$ \\
\hline $\begin{array}{l}\text { above-ground } \\
\text { biomass }\left(\mathrm{kg} / \mathrm{m}^{2}\right)\end{array}$ & 1.438 & 1.436 & 1.056 & 1.434 & 1.373 & 0.732 & 1.218 & 0.932 \\
\hline $\begin{array}{l}\text { under-ground } \\
\text { biomass }\left(\mathrm{kg} / \mathrm{m}^{2}\right)\end{array}$ & 0.586 & 0.623 & 0.433 & 0.394 & 0.338 & 0.296 & 0.342 & 0.412 \\
\hline growth height(cm) & 65.8 & 56.7 & 53.6 & 102.2 & 76.3 & 58.4 & 86.2 & 92.8 \\
\hline root depth $(\mathrm{cm})$ & 72.3 & 85.3 & 32.5 & 47.6 & 45.2 & 32.7 & 37.9 & 47.8 \\
\hline coverage(\%) & 89 & 85 & 86 & 83 & 85 & 79 & 92 & 62 \\
\hline density (plant $\cdot \mathrm{m}^{-2}$ ) & 124.7 & 127.4 & 2225 & 2563 & 2521 & 2124 & 2428 & 1978 \\
\hline green period (day) & 285 & 292 & 365 & 365 & 365 & 365 & 365 & 276 \\
\hline greenness (point) & $\begin{array}{l}\text { dark } \\
\text { green(9) }\end{array}$ & $\begin{array}{l}\text { dark } \\
\text { green(9) }\end{array}$ & Aqua(7) & dark green(9) & \begin{tabular}{|l} 
dark \\
green(9)
\end{tabular} & Aqua(7) & dark green $(9)$ & Aqua(7) \\
\hline growth rate (point) & $\begin{array}{l}\text { excellent }(8 \\
\text { ) }\end{array}$ & $\begin{array}{l}\text { excellent }(8 \\
)\end{array}$ & excellent(8) & excellent(9) & $\begin{array}{l}\text { excellent(8 } \\
\text { ) }\end{array}$ & excellent(8) & excellent(8) & $\begin{array}{l}\text { excellent }(9 \\
\text { ) }\end{array}$ \\
\hline Homogeneity (point) & $\begin{array}{l}\text { excellent }(8 \\
\text { ) }\end{array}$ & $\begin{array}{l}\text { excellent }(8 \\
\text { ) }\end{array}$ & excellent(8) & excellent(9) & $\begin{array}{l}\text { excellent }(9 \\
\text { ) }\end{array}$ & $\begin{array}{l}\text { excellent(7.5 } \\
\text { ) }\end{array}$ & excellent(9) & excellent $(8$ \\
\hline visual effect (point) & excellent(9 & excellent $(8$ & excellent(9) & $\begin{array}{l}\text { relatively } \\
\text { excellent(7) }\end{array}$ & \begin{tabular}{|l|} 
relatively \\
excellent(7 \\
\end{tabular} & excellent(9) & excellent(9) & $\begin{array}{l}\text { relatively } \\
\text { excellent } 6 \\
\text { ) }\end{array}$ \\
\hline thermostability (point) & \begin{tabular}{|l|} 
relatively \\
excellent(7 \\
)
\end{tabular} & $\begin{array}{l}\text { excellent }(8 \\
)\end{array}$ & excellent(9) & excellent(9) & excellent $(9$ & excellent(9) & excellent(8) & $\begin{array}{l}\text { relative } \\
\text { poor(3) }\end{array}$ \\
\hline cold endurance (point) & \begin{tabular}{|l|} 
excellent(8 \\
)
\end{tabular} & \begin{tabular}{|l|} 
excellent $(8$ \\
)
\end{tabular} & excellent(8) & \begin{tabular}{|l} 
relatively \\
excellent(7)
\end{tabular} & \begin{tabular}{|l|} 
excellent $(8$ \\
)
\end{tabular} & \begin{tabular}{|l} 
relatively \\
excellent(7)
\end{tabular} & \begin{tabular}{|l|} 
excellent(8.5 \\
)
\end{tabular} & $\begin{array}{l}\text { excellent }(9 \\
\text { ) }\end{array}$ \\
\hline drought tolerance (point) & $\begin{array}{l}\text { excellent }(8 \\
\text { ) }\end{array}$ & $\begin{array}{l}\text { excellent }(8 \\
\text { ) }\end{array}$ & excellent(8) & excellent(8) & excellent $(8$ & $\begin{array}{l}\text { excellent(7.5 } \\
\text { ) }\end{array}$ & excellent(8) & excellent $(9$ \\
\hline $\begin{array}{l}\text { disease and pest } \\
\text { resistance (point) }\end{array}$ & $\begin{array}{l}\text { excellent }(8 \\
\text { ) }\end{array}$ & $\begin{array}{l}\text { excellent }(8 \\
\text { ) }\end{array}$ & excellent(8) & excellent(8) & $\begin{array}{l}\text { excellent }(8 \\
\end{array}$ & excellent(8) & \begin{tabular}{|l|} 
excellent $(8.5$ \\
\end{tabular} & $\begin{array}{l}\text { excellent }(9 \\
\text { ) }\end{array}$ \\
\hline barren resistance (point) & $\begin{array}{l}\text { excellent }(8 \\
\text { ) }\end{array}$ & $\begin{array}{l}\text { excellent }(9 \\
\text { ) }\end{array}$ & excellent(8) & excellent(8) & $\begin{array}{l}\text { excellent }(8 \\
\end{array}$ & $\begin{array}{l}\text { Relatively } \\
\text { excellent(7) }\end{array}$ & excellent(9) & excellent $(9$ \\
\hline cost (yuan/kg) & $40-50$ & $70-90$ & $60-90$ & $20-40$ & $40-75$ & $80-100$ & $30-60$ & $10-30$ \\
\hline
\end{tabular}

From Table 2, we cannot tell which brush plant performs the best from both the qualitative and quantitative indicators. For quantitative indicators which indicates the growing conditions, like 
above-ground biomass, under-ground biomass, growth height, root depth, coverage, and density, the respective brush plants which performed the best are Crotalaria pallida Ait, Davidii Franch, Cajanus cajan(Linn.)Millsp, Davidii Franch, Crotalaria pallida Ait and Cajanus cajan(Linn.)Millsp. As for the green period which reflects the number of days when the plants keep green in a year, it shows that Hypericum monogynum Linn, Cajanus cajan(Linn.)Millsp, Tephrosia candida, Rhodomyrtus tomentosa Ait. and Crotalaria pallida Ait are green the whole round year. The higher qualitative indicators are, the better eco-adaptability is. Homogeneity and visual effect are the overall assessment for the appearance of lawn. High quality lawn has high evenness which gives a feel of beauty and harmony. Thermostability, cold endurance, drought tolerance, disease resistance, and barren resistance are the specific forms of overall resistance, especially drought tolerance and barren resistance, which are the significant factors affecting the greening effect of slope. According to the qualitative indicators, other plants performed well except that Amorpha fruticosa Linn. got a relatively worse thermostability.

Thus it can be seen that, for the single indicator, every plant gets advantages and disadvantages. We cannot select anoptimal project simply from the test monitoring results. If we want to find the most suitable plant, an overall assessment is needed.

The Adaptability Assessment of Subshrub Plant by Analytic Hierarchy Process. First, the establishment of hierarchical structural pattern. The target object layer is excellent slope protecting plants. The criterion layer includes output property B1, quality characteristic B2, stress resistance B3 and cost B4. The target layer includes the above-ground biomass $\mathrm{C} 1$, under-ground biomass $\mathrm{C} 2$, growth height $\mathrm{C} 3$, root depth $\mathrm{C} 4$, coverage $\mathrm{C} 5$, density $\mathrm{C} 6$, green period $\mathrm{C} 7$, greenness $\mathrm{C}$, growth rate $\mathrm{C} 9$, homogeneity $\mathrm{C} 10$, visual effect $\mathrm{C} 11$, thermostability $\mathrm{C} 12$, cold endurance $\mathrm{C} 13$, drought tolerance C14, disease and pest resistance C15, barren resistance C16, cost C17. Hierarchical chart is as shown in Fig.1.

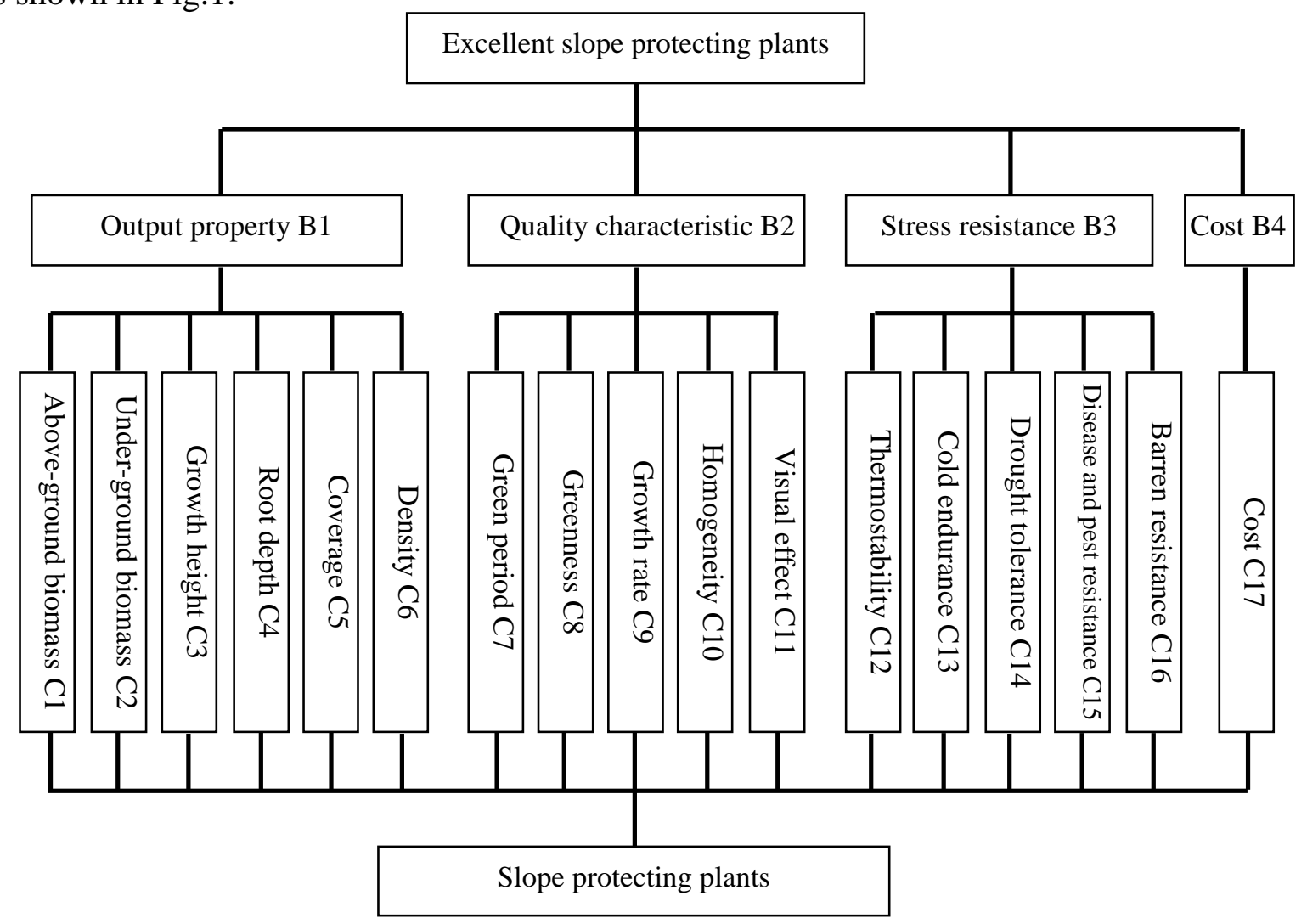

Fig.1. Hierarchical structure chart of selecting excellent slope protecting plants

Second, matrix for comparison and judgment, structural factor single taxis and homogeneity test. In order to identify the relative importance of every factor to the upper level, we quote 1 to 9 and its reciprocal analytical hierarchy process to construct judgment matrix. Judgment matrix A-B as shown in Table 3, the result of homogeneity test is R.I. $=0.9$, C.I. $=0.0035$, C.R. $=0.0038<0.10$, which meets the requirement of homogeneity, illustrating that the weight value is reasonable. 
Similarly, for the index layer judgment matrix, examine its homogeneity and ultimately determine its weight. There is no need to cover them in depth here, while the results are as shown in Table 4.

Table 3. Rule Hierarchical Judgment Matrix

\begin{tabular}{|c|c|c|c|c|c|c|}
\hline \multicolumn{2}{|c|}{ A Excellent slope protecting plants } & & operty & $\begin{array}{l}\text { B2 } \\
\text { quality characteristic }\end{array}$ & $\begin{array}{l}\text { B3 } \\
\text { stress resistance }\end{array}$ & $\begin{array}{l}\text { B4 } \\
\text { cost }\end{array}$ \\
\hline \multicolumn{2}{|l|}{ B1 output property } & 1 & & 3 & $1 / 2$ & 5 \\
\hline \multicolumn{2}{|c|}{ B2 quality characteristic } & $1 / 3$ & & 1 & $1 / 5$ & 2 \\
\hline \multicolumn{2}{|l|}{ B3 stress resistance } & 2 & & 5 & 1 & 8 \\
\hline \multicolumn{2}{|l|}{ B4 cost } & $1 / 5$ & & $1 / 2$ & $1 / 8$ & 1 \\
\hline \multicolumn{2}{|l|}{ single layer weight } & 0.29 & & 0.1082 & 0.5356 & 0.0599 \\
\hline \multicolumn{7}{|c|}{ Table 4. Index Layer Judgment Matrix } \\
\hline criterion layer B & \multicolumn{2}{|l|}{ index layer $\mathrm{C}$} & weight & \multicolumn{3}{|l|}{ homogeneity test } \\
\hline \multirow{6}{*}{ B1 output property } & \multicolumn{2}{|c|}{ C1 above-ground biomass } & 0.3232 & \\
\hline & \multicolumn{2}{|c|}{ C2 under-ground biomass } & 0.1855 & \multirow{4}{*}{\multicolumn{3}{|c|}{$\begin{array}{l}\lambda_{\max }=6.1355, \text { R.I. }=1.24, \text { C.I. }=0.0271 \text {, } \\
\text { C.R. }=0.0219<0.10, \text { meet the demand of } \\
\text { homogeneity }\end{array}$}} \\
\hline & \multicolumn{2}{|c|}{ C3 growth height } & 0.0411 & & & \\
\hline & \multicolumn{2}{|l|}{ C4 root depth } & 0.0670 & & & \\
\hline & \multicolumn{2}{|l|}{ C5 coverage } & 0.3340 & & & \\
\hline & \multicolumn{2}{|l|}{ C6 density } & 0.0492 & & & \\
\hline \multirow{5}{*}{$\begin{array}{l}\text { B2 quality } \\
\text { characteristic }\end{array}$} & \multicolumn{2}{|l|}{ C7 green period } & 0.3922 & \multirow{5}{*}{\multicolumn{3}{|c|}{$\begin{array}{l}\lambda_{\max }=5.0176, \text { R.I. }=1.12, \text { C.I. }=0.0044, \\
\text { C.R. }=0.0039<0.10, \\
\text { meet the demand of homogeneity }\end{array}$}} \\
\hline & \multicolumn{2}{|l|}{ C8 greenness } & 0.0424 & & & \\
\hline & \multicolumn{2}{|l|}{ C9 growth rate } & 0.1558 & & & \\
\hline & \multicolumn{2}{|c|}{ C10 homogeneity } & 0.0808 & & & \\
\hline & \multicolumn{2}{|c|}{ C11 visual effect } & 0.3289 & & & \\
\hline \multirow{5}{*}{$\begin{array}{l}\text { B3 stress } \\
\text { resistance }\end{array}$} & \multicolumn{2}{|c|}{ C12 thermostability } & 0.3266 & \\
\hline & \multicolumn{2}{|c|}{ C13 cold endurance } & 0.1794 & \multirow{3}{*}{\multicolumn{3}{|c|}{$\begin{array}{l}\lambda_{\max }=5.0153, R . I .=1.12, \text { C.I. }=0.0038, \\
C . R .=0.0034<0.10, \\
\text { meet the demand of homogeneity }\end{array}$}} \\
\hline & C14 barren resi & & 0.3266 & & & \\
\hline & \multicolumn{2}{|c|}{$\begin{array}{l}\text { C15 disease and pest } \\
\text { resistance }\end{array}$} & 0.1066 & & & \\
\hline & \multicolumn{2}{|c|}{ C16 barren resistance } & 0.0607 & & & \\
\hline B4 cost & \multicolumn{2}{|l|}{ C17 cost } & 1.0000 & $\begin{array}{l}\lambda_{\max }=1, R . I .=0.0 \\
\text { meet the demand of }\end{array}$ & $\begin{array}{l}\text { C.I. }=0, C . R .=0 \\
\text { omogeneity }\end{array}$ & 0.10 \\
\hline
\end{tabular}

Table 5. Project layer single-level sequencing

\begin{tabular}{|c|c|c|c|c|c|c|c|c|}
\hline \multirow[b]{3}{*}{ index layer } & \multicolumn{8}{|c|}{ project layer } \\
\hline & $\overline{G 1}$ & G2 & G3 & G4 & G5 & G6 & G7 & G8 \\
\hline & $\begin{array}{l}\text { Indigofera } \\
\text { amblyatha }\end{array}$ & $\begin{array}{l}\text { Davidii } \\
\text { Franch }\end{array}$ & $\begin{array}{l}\text { Hypericu } \\
\text { m } \\
\text { monogyn } \\
\text { um Linn }\end{array}$ & $\begin{array}{l}\text { Cajanus } \\
\text { cajan(Linn. } \\
\text { )Millsp }\end{array}$ & $\begin{array}{l}\text { Tephrosi } \\
\text { a candida }\end{array}$ & $\begin{array}{l}\text { Rhodomyrt } \\
\text { us } \\
\text { tomentosa } \\
\text { Ait. }\end{array}$ & $\begin{array}{l}\text { Crotalar } \\
\text { ia } \\
\text { pallida } \\
\text { Ait }\end{array}$ & $\begin{array}{l}\text { Amorpha } \\
\text { fruticosa } \\
\text { Linn. }\end{array}$ \\
\hline C1 above-ground biomass & 0.0857 & 0.0857 & 0.0526 & 0.1934 & 0.1304 & 0.0327 & 0.4026 & 0.0170 \\
\hline C2 under-ground biomass & 0.1389 & 0.2149 & 0.0859 & 0.1389 & 0.0569 & 0.0342 & 0.3120 & 0.0183 \\
\hline C3 growth height & 0.0769 & 0.0332 & 0.0332 & 0.4382 & 0.1591 & 0.0576 & 0.1687 & 0.0332 \\
\hline C4 root depth & 0.2143 & 0.3849 & 0.0450 & 0.1326 & 0.1031 & 0.0285 & 0.0295 & 0.0621 \\
\hline C5 coverage & 0.2021 & 0.1204 & 0.0743 & 0.0364 & 0.2162 & 0.0392 & 0.2911 & 0.0204 \\
\hline C6 density & 0.0384 & 0.0384 & 0.0585 & 0.1366 & 0.2185 & 0.0905 & 0.3999 & 0.0194 \\
\hline C7 green period & 0.0359 & 0.0640 & 0.1755 & 0.1755 & 0.1755 & 0.1755 & 0.1755 & 0.0224 \\
\hline C8 greenness & 0.1667 & 0.1667 & 0.0556 & 0.1667 & 0.1667 & 0.0556 & 0.1667 & 0.0556 \\
\hline C9 growth rate & 0.0935 & 0.2550 & 0.0935 & 0.2550 & 0.0935 & 0.0935 & 0.0935 & 0.0226 \\
\hline C10 homogeneity & 0.1687 & 0.1687 & 0.0592 & 0.1687 & 0.1687 & 0.0381 & 0.1687 & 0.0592 \\
\hline C11 visual effect & 0.1792 & 0.1792 & 0.1792 & 0.0402 & 0.0402 & 0.1792 & 0.1792 & 0.0237 \\
\hline C12 thermostability & 0.0650 & 0.0852 & 0.1668 & 0.1668 & 0.1668 & 0.1668 & 0.1668 & 0.0155 \\
\hline C13 cold endurance & 0.2362 & 0.1427 & 0.0849 & 0.0363 & 0.0849 & 0.0363 & 0.1427 & 0.2362 \\
\hline C14 barren resistance & 0.1059 & 0.1059 & 0.0256 & 0.1059 & 0.1059 & 0.0256 & 0.2626 & 0.2626 \\
\hline C15 disease and pest resistance & 0.1111 & 0.1111 & 0.1111 & 0.1111 & 0.1111 & 0.1111 & 0.2222 & 0.1111 \\
\hline C16 barren resistance & 0.0783 & 0.2181 & 0.0783 & 0.0783 & 0.0783 & 0.0325 & 0.2181 & 0.2181 \\
\hline C17 cost & 0.1089 & 0.0437 & 0.0437 & 0.2218 & 0.0817 & 0.0225 & 0.1239 & 0.3538 \\
\hline
\end{tabular}

Third, project layer single-level sequencing. The single-level sequencing of plants project layer observes the unicast test results by comparing above-ground biomass, under-ground biomass, lawn 
height, root depth and other aspects of the subshrub plants (Table 2) to give the order of excellence as shown in Table 5.

Fourth, the result of overall assessment. The overall assessment weight value of subshrub plants and general ranking are as shown in Table 6.

Table 6. The general ranking of project layer overall assessment result

\begin{tabular}{lll}
\hline A excellent subshrub slope protecting plant & final weight & general ranking \\
\hline G1 Indigofera amblyatha & 0.1213 & 4 \\
\hline G2 Davidii Franch & 0.1194 & 5 \\
\hline G3 Hypericum monogynum Linn & 0.0888 & 7 \\
\hline G4 Cajanus cajan(Linn.)Millsp & 0.1285 & 2 \\
\hline G5 Tephrosia candida & 0.1265 & 3 \\
\hline G6 Rhodomyrtus tomentosa Ait. & 0.0734 & 8 \\
\hline G7 Crotalaria pallida Ait & 0.2267 & 1 \\
\hline G8 Amorpha fruticosa Linn. & 0.1155 & 6 \\
\hline
\end{tabular}

As shown in Table 6, among the eight shrub plants, Crotalaria pallida Ait, Cajanus cajan(Linn.) Millsp and Tephrosia candida are the best with a better eco-adaptability and slope protecting function. Indigofera amblyatha and Davidii Franch come after them, while Rhodomyrtus tomentosa Ait. and Hypericum monogynum Linn are the worst. Therefore, we recommend that Crotalaria pallida Ait, Cajanus cajan(Linn.)Millsp and Tephrosia candida should be chosen as a first subshrub priority for Guanghe highway slope protecting vegetation.

\section{Conclusion}

First, we chose eight different plants from subshrub vegetation and conducted unicast experiment. The experiment measured quantitative indexes like above-ground biomass, under-ground biomass, growth height, root depth, coverage, density, green period and qualitative index like greenness, growth rate, homogeneity, visual effect, thermostability, cold endurance, barren resistance, disease and pest resistance to lay a foundation for the determination of the appropriate highway slope vegetation. However, we can see from the single index analysis, these plants all have their own advantages and disadvantages, and we cannot determine the optimal species. We need to establish an index assessment system and determine it by overall assessment.

Second, we conducted overall assessment for eco-adaptability of Guanghe highway slope subshrub vegetation by using Analytic Hierarchic Process and identified that among the eight shrub plants, Crotalaria pallida Ait, Cajanus cajan(Linn.)Millsp and Tephrosia candida are the best with a better eco-adaptability and slope protecting function. Indigofera amblyatha and Davidii Franch come after them, while Rhodomyrtus tomentosa Ait. and Hypericum monogynum Linn are the worst. Therefore, we recommend that Crotalaria pallida Ait, Cajanus cajan(Linn.)Millsp and Tephrosia candida should be chosen as a first subshrub priority for Guanghe highway slope protecting vegetation.

\section{Acknowledgements}

This work was financially supported by the National 12th Five Year Plan Water Project (2011ZX07104-002-04), Natural Science Foundation of China (51304106) and key scientific and technological project of Guangdong Transport Department. We would like to express our sincere gratitude!

\section{References}

[1] CHEN Ji-wen: Analysis on the Development Status and Countermeasures of Expressway Transportation in China [J]. Value Engineering. 5 (2015),p.191-192. 
[2] JIANG Yuan, TAO Yan, GU Wei, LIU Yong-bing, YU Hai-long: Assessment on Vegetation Restoration by Soil Spray Seeding Technique on Road Verge Slopes of Expressway [J]. Journal of Highway and Transportation Research and Development. 24(7) (2007), p.147-152.

[3] FU Jian-xin, TAN Yu-ye, SONG Wei-dong: Analysis on Stability of Unsaturated Soil Slope Considering Two Dimensional Rainfall Infiltration [J]. Journal of Northeastern University(Natural Science). 35(11)( 2014), p.1646-1649.

[4] ZHANG Jun-yun: MOISTURE BALANCE AND CONTROL OF BIO-SLOPE-ENGINEERING SYSTEM FOR ROCK SLOPE [J]. Chinese Journal of Rock Mechanics and Engineering. 32(9)(2013), p.1729-1735.

[5]CHANG Fei, LI Cai-xia: The slope protection technology of highway [J]. Highways \& Automotive Applications. 3 (2007), p.105-106.

[6]Esther Bochet and Patricio García-Fayos. Factors Controlling Vegetation Establishment and Water Erosionon Motorway Slopesin Valencia, Spain [J]. Restoration Ecology, 2004,12(2):p166-174.

[7] LIU Chun-Xia, HAN Lie-Bao: Review of researches in vegetation restoration of freeway slopes [J]. Acta Ecologica Sinica. 27(5) (2007), p.2090-2098.

[8] TAO Yan, JIANG Yuan, GU Wei, WANG Geng-rui: Experimental Research on Grass-shrub Disposition Model of Vegetation Restoration of Highway Side Slope [J]. Journal of Wuhan University of Technology, 30(6)(2008), p.70-73.

[9] YANG Hai-xia, XU Meng, LIU Ning, GUO Shao-xia: Effecte of arbuscular mycorrhizal fungi on salinity tolerance of two turfgrass [J]. Pratacultural Science, 31(7)(2014), p.1261-1268.

[10]LI Ying, ZENG Lei, ZHAO Gui-zhang: Evaluation on Ecological Vulnerability of the Vegetation in Subei Lake Watershed Based on Analytic Hierarchy Process [J]. Journal of Anhui Agricultural Sciences, 40(24)(2012), p.12158-12160.

[11] LI Xi-lin, WANG Lai-gui, LI Shun-wu, ZHANG Cheng-fe: Review on the research advances and the prospect of mining water resource evaluation [J]. Journal of Safety and Environment, 10(3) (2010), p.106-109.

[12] JIA Zhi-rong, ZHANG Wei: Evaluation Index and Method of Re-vegetation Quality on Highway Slope [J]. Bulletin of Soil and Water Conservation. 28(1)2008, p.115-118. 